\title{
Knowledge and Use of Caries Risk Assessment for Adult Patients Croatian Dentists
}

\section{Poznavanje i primjena procjene rizika za nastanak karijesa u odraslih pacijenata kod hrvatskih doktora dentalne medicine}

\author{
${ }^{1}$ Department of Endodontics and Restorative Dentistry, School of Dental Medicine, University of Zagreb, Croatia \\ Zavod za endodonciju i restaurativnu dentalnu medicinu Stomatološkog fakulteta Sveučilišta u Zagrebu, Hrvatska \\ 2 Department of Prosthodontics, School of Dental Medicine, University of Zagreb, Croatia \\ Zavod za mobilnu protetiku Stomatološkog fakulteta Sveučilišta u Zagrebu, Hrvatska \\ ${ }^{3}$ Aide Odontologique Internationale, Montrouge, France \\ Aide Odontologique Internationale, Montrouge, Francuska \\ ${ }^{4}$ CHU Estaing, Service d'Odontologie, France and Université Clermont Auvergne, UFR d'Odontologie, Centre de Recherche en Odontologie \\ Clinique EA 4847, F-63100 Clermont-Ferrand, France \\ CHU Estaing, Service d'Odontologie, Francuska i Université Clermont Auvergne, UFR d'Odontologie, Centre de Recherche en Odontologie \\ Clinique EA 4847, F-63100 Clermont-Ferrand, Francuska
}

\section{Abstract}

Objective: The aim of this study was to evaluate the usage of caries risk assessment (CRA) by Croatian general practitioners and evaluate their knowledge and attitudes towards CRA. Material and methods: A link to an online questionnaire was sent via e-mail to a sample of 1,500 general dentists in Croatia. The obtained data were analyzed using descriptive statistics, logistic regression analyses and chi-square tests. Results: Of 257 respondents, $47 \%$ performed CRA routinely, but only $4.5 \%$ of them used a specific CRA form. The significance of different factors in the development of a treatment plan varied considerably among respondents. Furthermore, in $77 \%$ of the respondents CRA was a basis for planning individual caries prevention (ICP). The association between CRA and ICP, and between CRA and treatment planning was statistically significant $(p=0.001)$. The practitioners doing CRA more often plan their treatment and ICP according to CRA. The use of CRA was not influenced by specialty and dentists' experience. Conclusions: In a considerable percentage (53\%) of Croatian general dentists, CRA is not part of their routine practice, and there is a strong association between the use of CRA and treatment plans and ICP. There is a need to promote the use of CRA in daily dental practice in Croatia.
Received: February 18, 2020.

Accepted: May 2, 2020

Address for correspondence Samir Čimić

University of Zagreb

School of Dental Medicine

Gundulićeva 5

Tel 003854802111

Fax 003854802159

scimic@sfzg.hr

Key words

Dental Caries; Risk Assessment; Croatia; Preventive Dentistry; Primary Prevention

\section{Introduction}

Dental caries is a dynamic process which depends on the balance between protective and pathogenic factors. Weak acids, produced as a result of bacterial metabolism of carbohydrates, cause demineralization of dental hard tissues (1). This process can be halted or reversed if the balance is shifted towards protective factors $(2,3)$. Preventing or arresting carious lesions requires a systematic approach towards assessing and monitoring the factors leading to demineralization, namely caries risk (CR) factors $(4,5)$.

For the purpose of assessing CR factors for individual patients, various tools have been developed. Based on the risk factors, treatment recommendations such as behavioral (oral hygiene and diet), chemical (fluoride), and minimally invasive procedures could be followed $(6,7)$. Caries prevalence and other specific characteristics of the population can influence the predictive validity of a caries risk assessment (CRA)

\section{Uvod}

Zubni karijes dinamičan je proces koji ovisi o ravnoteži između protektivnih i patogenih čimbenika. Slabe kiseline, koje su produkt bakterijskog metabolizma ugljikohidrata, uzrokuju demineralizaciju tvrdih zubnih tkiva (1). Taj se proces može zaustaviti ili reverzirati ako se ravnoteža pomakne prema protektivnim čimbenicima $(2,3)$. Preveniranje ili zaustavljanje karijesnih lezija zahtijeva sustavni pristup procjeni i praćenju čimbenika koji potiču demineralizaciju, konkretno rizičnim čimbenicima za nastanak karijesa (RK), $(4,5)$.

Za procjenu RK čimbenika kod individualnog pacijenta postoje različiti alati. Poslije procjene rizičnih čimbenika za nastanak karijesa slijede preporuke za postupanje, uključujući bihevioralne (oralna higijena i prehrana), kemijske (fluoridi) i minimalno invazivne postupke $(6,7)$. Na predviđenu validnost alata za procjenu rizika od nastanka karijesa (PRK) mogu utjecati prevalencija karijesa i ostale specifične karakte- 
tool. Different CRA tools are designed for different populations so that the predictive value of each predictor is maximized (8).

There are reports on the use of CRA in dental practice in France and Japan, but also in a dental practice based research network (DPBRN) covering different geographical regions (United States, Scandinavian countries and Japan) reflecting dentists at large (9-11). These reports suggest that CRA is not widely used in dental practice, and that the information obtained from CRA was not appropriately used to make treatment decisions (9-11). There are no data in the available literature toward the use of CRA by Croatian dental practitioners and its impact on treatment decisions.

The aim of this research was to determine the percentage of Croatian practitioners performing CRA, their ratings of the importance of specific CR factors in making a caries treatment plan in their adult patients, and to correlate the ratings of the specific risk factors with performing or not performing CRA. The research also aimed to determine to what extent they are informed about and interested in minimum intervention (MI) approaches in caries management.

\section{Material and methods}

\section{Study design and data collection}

The study has been reviewed independently and approved by the Ethics Committee of the School of Dental Medicine, University of Zagreb and conducted in full accordance with the World Medical Association Declaration of Helsinki. Since this was an online questionnaire, it was not possible to obtain a standard written informed consent with participants' signatures; hence the participants gave their online consent to participate in the study. The consent was approved by the above mentioned authorities.

The questionnaire used in this study was developed by Doméjean et al (9). It was originally available in both English and French but the English version was used for translation into Croatian by two bilingual (Croatian and English) dentists. The first Croatian version was discussed and harmonized, and then back-translated into English by a third dentist who was blinded concerning the original English version. The original English and back-translated versions of the questionnaire were compared by two experts (IM and $\mathrm{CH}$ ). After minor modifications, the Croatian version of the questionnaire was pilot-tested on a sample of 10 dentists at School of Dental Medicine in Zagreb, Croatia; no further modifications were required.

The questionnaire consisted of 22 questions: nine related to socio-demographic characteristics of the respondents, 10 to CRA use, individual caries prevention (ICP) and preferred management options in cariology and the last three to respondents' interest for further continuing education about CRA and their understanding of the minimal intervention concept.

\section{Participants}

The survey was administrated, to a random sample of 1500 dentists selected from the School of Dental Medicine ristike populacije. Različiti alati za PRK razvijeni su za različite populacije kako bi se maksimizirala predvidena vrijednost svakog prediktora (8).

Postoje radovi o primjeni PRK-a u općoj dentalnoj praksi u Francuskoj i Japanu, te u istraživačkoj mreži na temelju dentalne prakse (engl. DPBRN) koja obuhvaća različita geografska područja (SAD, skandinavske zemlje i Japan) te odražava dentalnu praksu na širem području $(9-11)$. Ti radovi sugeriraju da PRK nije u široj uporabi u dentalnoj praksi te da se informacije dobivene iz PRK-a ne koriste adekvatno u donošenju odluke o postupku $(9$ - 11). U dostupnoj literaturi nema informacija kako hrvatski stomatolozi primjenjuju PRK, ni o utjecaju njegove primjene na terapijske odluke.

Svrha ovog istraživanja bila je odrediti postotak hrvatskih dentalnih praktičara koji provode PRK, njihovo rangiranje specifičnih RK čimbenika u individualnom planu terapije i prevencije za odrasle pacijente te korelirati rangiranje pojedinih čimbenika rizika s provođenjem/neprovođenjem PRK-a. Svrha je također bila odrediti razinu informiranosti o minimalno intervencijskom (MI) pristupu terapiji karijesa i procijeniti zanimanje za njega.

\section{Materijal i postupci}

\section{Dizajn studije i prikupljanje podataka}

Protokol za istraživanje neovisno je recenziralo i odobrilo Etičko povjerenstvo Stomatološkog fakulteta Sveučilišta u Zagrebu. Istraživanje je provedeno u skladu s Helsinškom deklaracijom Svjetskoga medicinskog udruženja. S obzirom na to da je bilo u obliku upitnika na internetu, nije bilo moguće pribaviti uobičajeni potpis sudionika na informiranom pristanku te su svi internetski potvrdili da pristaju sudjelovati u istraživanju. Formular za pristanak također je odobrilo Etičko povjerenstvo.

Upitnik rabljen u ovom istraživanju sastavili su Doméjean i suradnici (9). U izvorniku je bio dostupan na engleskom i francuskom jeziku, a dva doktora dentalne medicine koji znaju oba jezika koristili su se engleskom verzijom za prijevod na hrvatski. Prva verzija na hrvatskome raspravljena je i usklađena te ju je treći doktor, koji nije vidio izvornu englesku verziju, ponovno preveo na engleski. Dva stručnjaka usporedila su izvornik i ponovno prevedenu inačicu (I. M. i C. H.). Nakon manjih prilagodbi, hrvatska verzija upitnika testirana je u pilot-studiji na uzorku od 10 doktora dentalne medicine na Stomatološkom fakultetu u Zagrebu, Hrvatska. Daljnje modifikacije nisu bile potrebne.

Upitnik se sastojao od 22 pitanja - devet se odnosilo na socijalno-demografski profil ispitanika, deset na primjenu PRK, individualnu prevenciju karijesa (IPK) i preferirani postupak u sklopu karijesologije, a posljednja tri pitanja odnosila su se na interes prema trajnoj edukaciji o PRK-u i na razumijevanje koncepta minimalne intervencije.

\section{Sudionici}

Upitnik je s pomoću platforme SurveyMonkey poslan na 1500 e-adresa nasumično odabranih iz baze adresa doktora 
Zagreb University's database of Croatian dentists and registered dental offices in Croatia, via e-mail using Survey Monkey". The survey was anonymous.

\section{Statistical methods}

The data obtained were analyzed using descriptive statistics. Logistic regression analysis was used with the CRA (dichotomous variable) as dependent variable and dentists' experience and specialty as factors. Chi-square tests were used to test if there was significance of the differences between the CRA and ICP, and between CRA and treatment plan. The level of significance was set at $\mathrm{P}<0.05$. Statistical analysis was performed using Statistical Package for the Social Sciences (SPSS), version 20 (trial version) (IBM corp, Armonk, New York, USA).

\section{Results}

The response rate was $17.1 \%(\mathrm{n}=257)$. Table 1 shows that the socio-demographic characteristics of respondents were similar to those of general population of Croatian dentists. More than $60 \%$ of Croatian dentists work in private dental practices and have a contract with the National Social Health insurance fund - the Croatian Institute for Health Insurance; others work for a fixed salary at health centers.

There was great variation among respondents with respect to the importance given to different factors to be considered for the development of a treatment plan (Figure 1). Oral hygiene and the presence of active caries lesions were rated as the most important factors.

Oral hygiene (29.7\%), patient motivation (13.4\%) and nutritional habits (11.3\%) were considered the most impor- dentalne medicine i registriranih dentalnih ordinacija u $\mathrm{Hr}$ vatskoj Stomatološkog fakulteta Sveučilišta u Zagrebu. Upitnik je bio anoniman.

\section{Statistički postupci}

Dobiveni podatci analizirani su s pomoću deskriptivne statistike. Logistička regresija korištena je za analizu PRK kao zavisne varijable uz čimbenike iskustva stomatologa i specijalizacije. Chi-kvadrat test korišten je za testiranje razlika između PRK-a i IPK-a te između PRK-a i terapijskog plana. Razina značajnosti postavljena je na $\mathrm{p}<0,05$. Statistička analiza obavljena s pomoću SPSS paketa verzija 20 (IBM corp, Armonk, New York, SAD).

\section{Rezultati}

Stopa odgovora bila je $17,1 \%(\mathrm{n}=257)$. Tablica 1. pokazuje da su socijalno-demografske karakteristike sudionika slične onima u općoj populaciji hrvatskih stomatologa.

Više od $60 \%$ hrvatskih stomatologa radi u privatnim ordinacijama koje imaju ugovor s Hrvatskim zavodom za zdravstveno osiguranje ili rade za fiksne plaće u domovima zdravlja.

Odgovori ispitanika veoma su različiti kad je riječ o važnosti različitih čimbenika koje treba uzeti u obzir pri planiranju terapijskoga plana (slika 1.). Pritom su kao najvažniji ocijenjeni oralna higijena i aktivna karijesna lezija.

Oralna higijena $(29,7 \%)$, motivacija pacijenta $(13,4 \%)$ i prehrambene navike (11,3\%) procijenjeni su kao najvažniji čimbenici za procjenu rizika od nastanka karijesa u odra-

Table 1 Demographic characteristics of the sample dentists and general population dentists in Croatia.

Tablica 1. Demografske karakteristike stomatologa i stomatologa općenito u Hrvatskoj

Demographic characteristics

\begin{tabular}{|c|c|c|c|}
\hline Demographic characteristics & \multicolumn{3}{|c|}{ Respondents; n=257 } \\
\hline \multirow{2}{*}{ Gender (n) } & Male & 71 & $27.6 \%$ \\
\hline & Female & 186 & $72.3 \%$ \\
\hline \multirow{3}{*}{ Age (years) } & Mean & 40.5 years & \pm 10.1 years \\
\hline & Min & 24 & \\
\hline & Max & 71 & \\
\hline \multirow{2}{*}{ Year of graduation } & More than 15 years from graduation & 126 & $49 \%$ \\
\hline & Less than 15 years from graduation & 131 & $51 \%$ \\
\hline \multirow{4}{*}{ University of graduation } & Zagreb & 225 & $87.6 \%$ \\
\hline & Rijeka & 23 & $9 \%$ \\
\hline & Split & 2 & $0.8 \%$ \\
\hline & Elsewhere (foreign University) & 7 & $2.9 \%$ \\
\hline \multirow{2}{*}{ Working in clinical practice } & Yes & 236 & $91.8 \%$ \\
\hline & No & 21 & $8.2 \% *$ \\
\hline Working in private practice & Yes & 160 & $62.3 \%$ \\
\hline \multirow{2}{*}{ Cont. education in cariology in past 5 years } & Yes & 152 & $59.4 \%$ \\
\hline & No & 105 & $40.9 \%$ \\
\hline \multirow{2}{*}{ Reading scientific articles on MI } & Yes & 227 & $88.3 \%$ \\
\hline & No & 30 & $11.7 \%$ \\
\hline
\end{tabular}



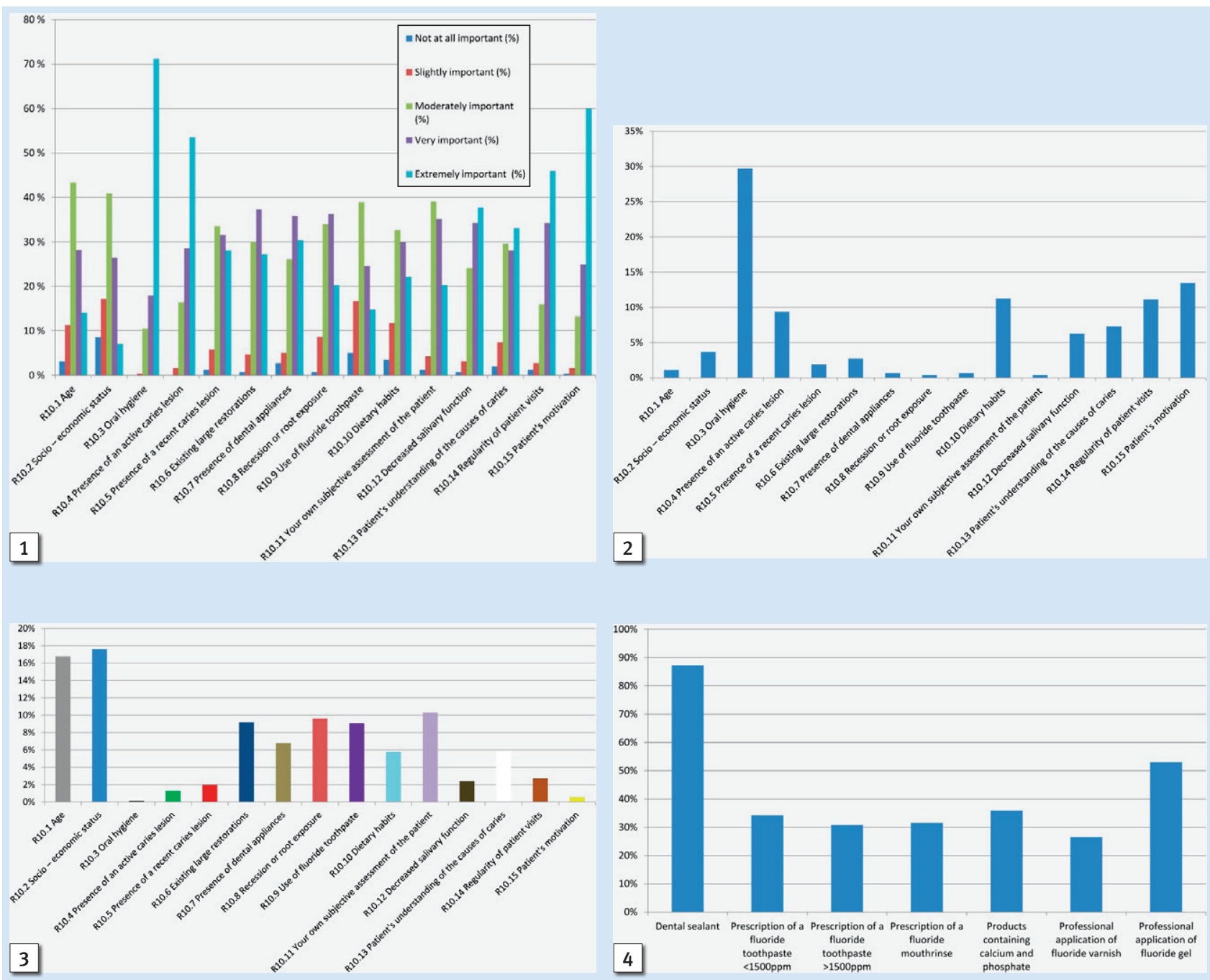

Figure 1 Respondents' answers about the factors that influence a treatment plan for patients $\geq 18$ years old $(N=257)$.

Slika 1. Odgovori ispitanika o čimbenicima koji utječu na plan liječenja za pacijente starije od 18 godina ( $\mathrm{N}=257)$.

Figure 2 Respondents' answers about the most important factors for CRA for patients $\geq 18$ years old $(\mathrm{N}=257)$.

Slika 2. Odgovori ispitanika o najvažnijim čimbenicima CRA-e za pacijente starije od 18 godina $(\mathrm{N}=257)$.

Figure 3 Respondents answers about the least relevant or irrelevant factors for the CRA for patients $\geq 18$ years old $(\mathrm{N}=257)$.

Slika 3. Ispitanici odgovaraju na najmanje relevantne ili nevažne čimbenike CRA za pacijente starije od 18 godina $(\mathrm{N}=257)$.

Figure 4 Respondents' answers about the used preventive treatment

Slika 4. Odgovori ispitanika o korištenom preventivnom liječenju.

tant factors in estimating CR for their adult patients, while socio-economic status, age and a subjective judgment were considered to be the least important factors (Figures 2 and 3).

Of the respondents, $47 \%$ reported that CRA was part of their routine practice, but only $4.5 \%$ did so using a specific evaluation form. Moreover, $77 \%$ of the respondents plan ICP based on the CRA. Treatment plans according to the individual patient's CR established $68.1 \%$ of the respondents, while $31.9 \%$ did not. The most common form of prevention used were pits and fissure sealants $(87.2 \%)$ with topical application of fluoride gel as the second most used (52.9\%), (Figure 4). There was statistically significant association between CRA and ICP $(p<0.001)$, and between CRA and treatment plan $(\mathrm{p}=0.001)$. The respondents who performed CRA were more likely to plan ICP and modify their treatment plan according to CRA. The results also showed that dentists' experience did not influence the use of CRA ( $\mathrm{p}=0.531)$. slih pacijenata, a socijalno-ekonomski status, dob i subjektivna prosudba smatrani su najmanje važnima (slike 2. i 3.).

Među ispitanicima njih $47 \%$ provodi PRK u rutinskoj praksi, no samo $4,5 \%$ to čini koristeći se specifičnim evaluacijskim formularom. Terapijski plan prema individualnom riziku od nastanka karijesa planira 68,1 \% ispitanika, a 31,9 $\%$ to ne čini. Najčešći oblik prevencije jest pečaćenje fisura $(87,2 \%)$, a na drugom mjestu je topikalna aplikacija fluoridnog gela $(52,9 \%)$ (slika 4.). Između PRK-a i individualne prevencije karijesa je statistički značajna veza $(\mathrm{p}<0,001)$, kao $\mathrm{i}$ između PRK-a i terapijskoga plana $(\mathrm{p}=0,001)$. Ispitanici koji provode PRK vjerojatnije planiraju individualnu prevenciju karijesa i modificiraju svoj terapijski plan prema PRK-u. Rezultati su također pokazali da iskustvo nije utjecalo na primjenu PRK-a $(\mathrm{p}=0,531)$. 


\section{Discussion}

This is the first study to assess Croatian dentists' subjective ratings of specific CR factors in making a caries treatment plan in their adult patients, and about the percentage of Croatian practitioners performing CRA. Unfortunately, the response rate to the questionnaire was rather low (17.1\%), similar to Mayer et al study (12). This might partially be due to the use of an internet based questionnaire since the response rate in a similar postal questionnaire survey undertaken in France in 2015 was considerably higher (34.7\%), (9). It should, however, be noted that in the CAMBRA study of Rechmann et al (13), even though dentists were informed through a newsletter about the study, the response rate was only $13.7 \%$, as well as in a study about the restorative threshold where an online questionnaire survey was used, and the response rate was $11.3 \%$ (14). Nevertheless, the demographic data of the survey respondents and practitioners at national level are relatively comparable (general population of dentists in Croatia, $\mathrm{n}=5062$, males $=33.8 \%$, females $=66.2 \%)$.

It is interesting to note that while $47 \%$ of respondents reported the use of CRA as part of their routine practice, $77 \%$ of all respondents claim to plan ICP based on a CRA. This might be due to a problem with the interpretation of the question "Do you establish your treatment plans, according to the individual patient's CR", where a dentist's overall impression of CR might not necessarily be consistent with a full and proper CRA. Furthermore, health insurance in Croatia is dominated by the Croatian Institute for Health Insurance system which covers most dental procedures but does not include CRA as a diagnostic-therapeutic procedure and it is, therefore, not compensated. This is probably the reason why the practitioners who lack time are not motivated to systematically perform a full and proper CRA but still base their preventive and therapeutic strategies on their impression of CR. This might also explain why only $47 \%$ of respondents perform CRA, and only $4.5 \%$ use a specific form.

There appears to be lack of consensus among Croatian practitioners on the priority of certain CR factors. This may be explained by the fact that there are no national recommendations about CRA and caries management according to the assessed risk. Moreover, most of the CRA systems are not officially available in Croatia for a wider population of dental practitioners, but are merely present in academic settings. Practitioners in Croatia find oral hygiene far most important factor in assessing CR, followed by a patient's motivation and diet. A similar tendency was observed in France (9), where practitioners singled out oral hygiene, diet and the patient's motivation. Oral hygiene was also considered important by DPBRN dentists from United States, Denmark, Norway and Sweden, along with salivary flow (10). In the Trueblood et al study (Texas), practitioners had different perceptions as they considered diet and caries history the most important (15).

We have noticed that respondents insufficiently recognized the presence of an active carious lesion as risk factor, but this might be due to the fact that it is rather difficult for practitioners to assess the lesion activity, since the combined information obtained from visual appearance, location of the

\section{Rasprava}

Ovo je prva studija koja se bavi subjektivnim vrjednovanjem specifičnih rizičnih čimbenika za nastanak karijesa i njihovom primjenom pri planiranju tretmana karijesa u odraslih pacijenata te postotkom hrvatskih praktičara koji primjenjuju PRK. Nažalost, stopa odgovora na upitnik bila je dosta niska (17,1 \%), slično kao i u studiji Mayera i suradnika (12). To je možda djelomično tako zato što je korišten upitnik na internetu, jer je stopa odgovora u sličnom istraživanju provedenom u Francuskoj 2015. godine, gdje je upitnik poslan poštom, bila znatno veća $(34,7 \%)$, (9). Ipak valja istaknuti da je i u studiji CAMBRA Rechmanna i suradnika (13), bez obzira na informiranje stomatologa o studiji u obavijesnom pismu, stopa odgovora bila samo $13,7 \%$, kao i u studiji o restaurativnom pragu u kojoj je rabljen on-line upitnik, a stopa odgovora bila je 11,3 \% (14). Međutim, demografske karakteristike ispitanika koji su odgovorili na upitnik i stomatologa praktičara na nacionalnoj razini, razmjerno su usporedivi (opća populacija stomatologa u Hrvatskoj n = 5062, muškar$\mathrm{ci}=33,8 \%$, žene $=66,2 \%)$.

Zanimljivo je da je $47 \%$ ispitanika odgovorilo kako rabi PRK u svojoj rutinskoj praksi, a čak $77 \%$ svih ispitanika tvrdi da planira individualnu prevenciju karijesa prema PRK-u. To je možda zbog problema u interpretaciji pitanja koje glasi: Ustanovljujete li plan terapije prema individualnom pacijentovu riziku od nastanka karijesa?, pri čemu se stomatologovo sveukupno shvaćanje rizika za nastanak karijesa ne mora nužno odnositi na potpuni i sistematični PRK. Nadalje, zdravstveno osiguranje u Hrvatskoj dominantno obuhvaća Hrvatski zavod za zdravstveno osiguranje koji plaća većinu dentalnih postupaka, no ne uključuje PRK kao dijagnostičko-terapijski postupak, pa se zato taj postupak i ne nadoknađuje. Vjerojatno je to razlog da stomatolozi kojima nedostaje vremena nisu motivirani PRK provoditi sistematično i potpuno, pa i dalje temelje svoje preventivne i terapijske strategije na osobnom dojmu rizika od nastanka karijesa. To takoder može objasniti zašto samo $47 \%$ ispitanika primjenjuje PRK, a samo 4,5\% koristi se specifičnim formularom.

Čini se da među hrvatskim stomatolozima nema konsenzusa o prioritetnim čimbenicima za rizik od nastanka karijesa. To se može objasniti činjenicom da na nacionalnoj razini nema preporuke za provedbu PRK-a i preporuke za tretman karijesa prema procijenjenom riziku. Nadalje, većina PRK sustava nije službeno dostupna u Hrvatskoj za širu populaciju stomatologa praktičara, nego se primjenjuju samo u akademskim krugovima. Hrvatski praktičari smatraju oralnu higijenu najvažnijim čimbenikom u procjeni rizika od nastanka karijesa, a slijede pacijentova motivacija i prehrana. Slična tendencija uočena je i u Francuskoj (9) gdje su praktičari izdvojili oralnu higijenu, prehranu i motivaciju pacijenta. Važnost oralne higijene je, uz salivaciju, također prepoznata $\mathrm{u}$ DPBRN stomatologa u SAD-u, Danskoj, Norveškoj i Švedskoj (10). U istraživanju Trueblooda i suradnika (Texas) (15), praktičari su imali drukčiju percepciju te su smatrali najvažnijima prehranu i dotadašnji karijes.

Moramo istaknuti da ispitanici nedovoljno prepoznaju pojavu aktivne karijesne lezije kao čimbenik rizika, no to se 
lesion, tactile sensation during probing and gingival health must be considered (16).

Furthermore, socioeconomic factors were estimated by the respondents in our study as the least important factors in assessing CR, followed by a subjective assessment of the patient. However, socio-demographic factors were shown to influence the prevalence of oral diseases, and the risk factor is proposed as relevant for CRA $(8,15,17,18)$. It is, therefore, hard to explain the low rating of socio-economic factors. It is very likely that the social climate of "political correctness" made the respondents choose this answer. Furthermore, a subjective evaluation certainly has its merit and there are studies that evaluated clinicians' subjective assessment and treatment decision, where more skilled dentists are less likely to perform CRA $(19,20)$. It was reported that the dentist's subjective judgment increases sensitivity in the risk assessment process (20).

Our results also showed that there was no significant difference between the respondents considering the year of graduation, although the curriculum was changed. Cariology was only introduced into the undergraduate curriculum in 2006. However, as explained above, there are no official recommendations about CRA at the national level, and there are no CRA systems available in the Croatian language outside academic setting that would be recognized by the National Health Insurance Fund as a chargeable diagnostic procedure. This is probably the reason, apart from the lack of time, why even more recent graduates in Croatia are not encouraged to perform CRA despite having been taught CRA and MI concepts since 2006. However, there are procedures that the $\mathrm{Na}$ tional Health Insurance Fund compensates, that promote the concept of MI, such as first examination and recording initial dental/oral status, patient motivation, fluoridation, control exam, oral hygiene instructions and fissure sealing.

Croatia has relatively recently joined the European Union (2013) and DMFT is higher than in other EU countries (21). In an attempt of designing a specific CRA tool for a population with high DMFT, such as the case in Croatia, it should be considered that a strong predictor of future caries - past caries experience, cannot simply be assessed from the DMFT index value since it does not inform about the factors to be corrected to counterbalance the risk to develop further lesions (8). The present paper shows that there is a need for combined efforts of the universities, professional associations, such as the Society for Minimally Invasive Dentistry in Croatia, the Croatian Dental Chamber and the Croatian Institute for Health Insurance to develop MI and CRA that would be practical and efficient for Croatian patients in a specific health care model.

\section{Conclusions}

This study revealed that Croatian dental practitioners have considered oral hygiene, patient's motivation and diet as most important factors in assessing caries risk. Most den- može dogoditi zato što je praktičarima razmjerno teško procijeniti je li lezija aktivna, s obzirom na to da je potrebno uzeti u obzir kombinaciju informacija dobivenih na temelju izgleda, lokacije lezije, taktilnog osjećaja pri sondiranju i zdravlja gingive (16).

Nadalje, ispitanici u našem istraživanju ocijenili su socijalno-demografske čimbenike kao najmanje važne u PRK-u, a slijedila je subjektivna procjena. No utvrđeno je da socijalnodemografski čimbenici utječu na prevalenciju oralnih bolesti te je taj rizični čimbenik u PRK-u relevantan $(8,15,17,18)$. Teško je stoga objasniti to nisko rangiranje važnosti socijalnodemografskih čimbenika. Možda je društvena klima političke korektnosti pridonijela takvom stajalištu. Nadalje, subjektivna procjena sigurno ima vrijednost, a neke su evaluacijske studije o subjektivnoj procjeni kliničara i odlukama o postupcima pokazale kako je manja vjerojatnost da iskusniji stomatolozi provode PRK $(19,20)$. Navodi se da subjektivna procjena stomatologa povećava osjetljivost u procesu procjene rizika (20).

Naši su rezultati također pokazali da nije bilo značajne razlike među ispitanicima s obzirom na godinu diplomiranja i bez obzira na promjene u kurikulu. Karijesologija je uvedena u dodiplomski studij 2006. godine. No kako je prije objašnjeno, ne postoje službene preporuke za postupanje kad je riječ o PRK-u na nacionalnoj razini te nema dostupnih službenih formulara za PRK na hrvatskom jeziku izvan akademskog okružja, a provedbu kojih bi HZZO prepoznao kao naplativu kategoriju. To je vjerojatno razlog, uz nedostatak vremena, zašto i mlađi doktori dentalne medicine u Hrvatskoj nisu potaknuti za provedbu PRK-a, bez obzira na to što su od 2006. godine poučavani o njoj i o konceptima minimalno-intervencijske dentalne medicine. Ipak, HZZO kompenzira neke postupke koji su u skladu s konceptima MI dentalne medicine, poput prvog pregleda, bilježenja inicijalnog dentalnog/oralnog statusa, motivacije pacijenta, fluoridacije, kontrolnog pregleda, upućivanja u oralnu higijenu i pečaćenje fisura.

Hrvatska je razmjerno nedavno pristupila Europskoj uniji (2013.), a KEP indeks veći je negoli u drugim zemljama EU-a (21). U nastojanju da se osmisli specifični formular za PRK u populaciji s visokim KEP indeksom kakva je hrvatska populacija, valja imati na umu da se snažan prediktor karijesa u budućnosti - dosadašnje iskustvo o karijesu, ne može jednostavno procijeniti iz vrijednosti KEP indeksa s obzirom na to da on ne informira o čimbenicima koje treba ispraviti kako bi se ostvarila proturavnoteža s čimbenicima koji pridonose daljnjem razvoju lezije (8). Ovo istraživanje pokazuje da su potrebni uzajamni napori sveučilišta, profesionalnih udruga poput Hrvatskoga društva za minimalno intervencijsku dentalnu medicinu, Hrvatske komore dentalne medicine i HZZO-a, u svrhu razvoja MI-ja i PRK-a koji bi bili praktični i učinkoviti za hrvatske pacijente u specifičnom zdravstvenom sustavu.

\section{Zaključci}

Ovo je istraživanje pokazalo da hrvatski stomatolozi praktičari smatraju oralnu higijenu, motivaciju pacijenta i prehranu najvažnijim čimbenicima u procjeni rizika od nastanka 
tists plan individual caries prevention based on caries risk assessment. Still, most of practitioners do not assess caries risk using a specific evaluation form. There is a need to encourage the use of CRA systems in Croatia.

\section{Conflict of interest}

The authors declare that they have no competing interest

\section{Acknowledgements}

This study was funded by the Croatian Science Foundation, "Investigation and development of new micro and nanostructure bioactive materials in dental medicine" BIODENTMED No. IP-2018-01-1719. karijesa. Većina planira individualnu prevenciju karijesa na temelju PRK. Ipak, većina praktičara ne procjenjuje rizik koristeći se specifičnim evaluacijskim formularima. Potrebno je poticati primjenu sustava za PRK u Hrvatskoj.

\section{Sukob interesa}

Nije ga bilo.

\section{Zahvale}

Ovu studiju financirala je Hrvatska zaklada za znanost, „Istraživanje i razvoj novih mikro i nanostrukturnih bioaktivnih materijala u dentalnoj medicini” BIODENTMED br. IP-2018-01-1719.

\section{Sažetak}

Svrha rada: Svrha istraživanja bila je evaluirati upotrebu procjene rizika za nastanak karijesa (PRK) kod hrvatskih općih stomatologa i procijeniti njihovo znanje i stajališta o PRK-u. Materijal i postupci: Poveznica za on-line upitnik poslana je na e-adrese 1500 stomatologa u Hrvatskoj. Dobiveni podatci analizirani su s pomoću deskriptivne statistike, logističke regresije i Chi-kvradrat testa. Rezultati: Od 257 ispitanika njih $47 \%$ obavlja PRK rutinski, a samo se 4,5\% pritom koristi specifičnim formularima. Među ispitanicima znatno je varirala važnost različitih čimbenika pri pripremi plana terapije. Nadalje, $77 \%$ ispitanika temeljilo je individualnu prevenciju (IPK) karijesa na PRK-u. Veza između PRK i IPK te PRK i plana terapije bila je statistički značajna $(p=0,001)$. Praktičari koji primjenjuju PRK češće planiraju terapiju i provode IPK prema PRK-u. Na uporabu PRK-a nisu utjecali ni specijalizacija, ni iskustvo stomatologa. Zaključci: Velikom dijelu (53\%) hrvatskih općih stomatologa PRK nije dio rutinske prakse i postoji značajna povezanost između njegove primjene i planiranja terapije te IPK. Potrebno je promicati uporabu PRK-a u svakodnevnoj dentalnoj praksi u Hrvatskoj.
Zaprimljen: 18. veljače 2020.

Prihvaćen: 2. svibnja 2020.

Adresa za dopisivanje

Samir Čimić

Sveučilište u Zagrebu

Stomatološki fakultet

Zavod za mobilnu protetiku

Gundulićeva 5

tel: 003854802111

faks: 003854802159

scimic@sfzg.hr

Ključne riječi

zubni karijes; procjena rizika; Hrvatska; preventivna stomatologija; primarna prevencija

\section{References}

1. Selwitz RH, Ismail Al, Pitts NB. Dental caries. Lancet. 2007 Jan 6;369(9555):51-9.

2. Pinheiro SL, Azenha GR, DE Milito F, Democh YM. Antimicrobial Capacity of Casein Phosphopeptide/Amorphous Calcium Phosphate and Enzymes in Glass Ionomer Cement in Dentin Carious Lesions. Acta Stomatol Croat. 2015;49(2):104-11.

3. Featherstone JD. Caries prevention and reversal based on the caries balance. Pediatr Dent. 2006 Mar-Apr;28(2):128-32; discussion 192-8.

4. Cerón-Bastidas XA, Suarez A, Guauque-Olarte S. Differences in Caries Status and Risk Factors among Privileged and Unprivileged Children in Colombia. Acta Stomatol Croat. 2018;52(4):330-9.

5. Erika V, Modrić, Verzak Ž, Karlović Z. Developmental Defects of Enamel in Children with Intellectual Disability. Acta Stomatol Croat. 2016;50(1):65-71.

6. Young DA, Featherstone JD, Roth JR. Curing the silent epidemic: caries management in the 21st century and beyond. J Calif Dent Assoc. 2007 Oct;35(10):681-5.

7. Caries Risk Assessment and Management Prepared by: Center for Scientific Information, ADA Science Institute Reviewed by: Caries Workgroup, ADA Council on Scientific Affairs Topic last updated: July 12, 2017.

8. Zero D, Fontana M, Lennon AM. Clinical applications and outcomes of using indicators of risk in caries management. J Dent Educ. 2001 Oct;65(10):1126-32.

9. Doméjean S, Léger S, Simon A, Boucharel N, Holmgren C. Knowledge, opinions and practices of French general practitioners in the assessment of caries risk: results of a national survey. Clin Oral Investig. 2017;21(2):653-63.

10. Riley JL 3rd, Gordan VV, Ajmo CT, Bockman H, Jackson MB, Gilbert GH, Dental PBRN Collaborative Group. Dentists' use of caries risk assessment and individualized caries prevention for their adult patients: findings from The Dental Practice-Based Research Network. Community Dent Oral Epidemiol. 2011 Dec;39(6):564-73.
11. Kakudate N, Sumida F, Matsumoto Y, Yokoyama Y, Riley JL 3rd, Gilbert GH, et al. Dentists' decisions to conduct caries risk assessment in a Dental Practice-Based Research Network. Community Dent Oral Epidemiol. 2015 Apr;43(2):128-34.

12. Mayer E, Klapper HU, Nitschke I, Hahnel S. Observations, knowledge, and attitude towards treatment options in patients with dry mouth: a survey among German dentists. Clin Oral Investig. 2019 Dec;23(12):4189-4194.

13. Rechmann P, Jue B, Santo W, Rechmann BMT, Featherstone JDB. Calibration of dentists for Caries Management by Risk Assessment Research in a Practice Based Research Network - CAMBRA PBRN. BMC Oral Health. 2018 Jan 4;18(1):2.

14. Rechmann P, Doméjean S, Rechmann BM, Kinsel R, Featherstone JD. Approximal and occlusal carious lesions: Restorative treatment decisions by California dentists. J Am Dent Assoc. 2016 May;147(5):328-38.

15. Trueblood R, Kerins CA, Seale NS. Caries risk assessment prac tices among Texas pediatric dentists. Pediatr Dent. 2008 JanFeb;30(1):49-53.

16. Ekstrand KR, Zero DT, Martignon S, Pitts NB. Lesion activity assessment. Monogr Oral Sci. 2009;21:63-90.

17. Fontana M, Zero DT. Assessing patients' caries risk. J Am Dent Assoc. 2006 Sep;137(9):1231-9.

18. Fontana M, Young DA, Wolff MS. Evidence-based caries, risk assessment, and treatment. Dent Clin North Am. 2009 Jan;53(1):149$61, x$.

19. Bader JD, Perrin NA, Maupomé G, Rush WA, Rindal BD. Exploring the contributions of components of caries risk assessment guidelines. Community Dent Oral Epidemiol. 2008 Aug;36(4):357-62.

20. Bader JD, Shugars DA. What do we know about how dentists make caries-related treatment decisions? Community Dent Oral Epidemiol. 1997 Feb;25(1):97-103.

21. Radić M, Benjak T, Dečković Vukres V, Rotim Ž, Filipović Zore I. Presentation of DMFT/dmft Index in Croatia and Europe. Acta Stomatol Croat. 2015;49(4):275-84 